\title{
Charitable giving and nonbinding contribution-level suggestions Evidence from a field experiment
}

\author{
Maja Adena (WZB), Steffen Huck (WZB \& UCL), Imran Rasul (UCL)*
}

November 2013

When asking for donations, charitable organizations often suggest a potential amount to contribute. However, the evidence concerning the effects of such suggestions is scarce and inconsistent. Unlike the majority of earlier studies concerned with small-money solicitations, we examine the effect of larger nonbinding suggestions in the context of middle-range donations which are relevant in practice. In a randomized field experiment conducted in conjunction with the Bavarian State Opera, opera visitors received solicitation letters asking to support a social youth project organized by the opera house. The three different treatments were: no suggestion and suggestions of $€ 100$ and $€ 200$, respectively. Both suggestions were larger than average and median donations in this context. We find that suggested contribution levels substantially influence the distribution of donations actually received. The mean amounts given increase significantly if a suggestion is made. The increase is stronger in the $€ 200$ treatment. On the other hand, the participation rate decreases if a suggestion is made. Overall, the returns from the campaign increase non-significantly when a suggestion is made. The solicitation was repeated a year later, without any suggestion. There is weak evidence that suggestions have a long-term effect on individual contribution-level decisions.

\section{Introduction}

Charitable organizations widely use contribution-level suggestions (Croson and Marks 2001, Desmet and Feinberg 2003). There is no clear theoretical rationale for using suggestions and empirical evidence is scarce and inconsistent. Traditional public good theory predicts no

\footnotetext{
* We thank all those at the Munich Opera House for making this project possible. This paper has been screened to ensure no confidential information is revealed.
} 
effects of nonbinding suggestions but suggestions might provide some informational cues similarly to prices in the private good context. Potential donors cannot easily ascertain the quality of the charitable output because they are not among the direct beneficiaries and because they make their contributions before the actual final good is produced. Hence, donors might find it difficult to determine their optimal donation level and suggestions could offer guidance. One could also think of suggestions as being helpful for coordination on a particular equilibrium as individuals find it difficult to predict how many others will contribute and thus what their fair share could be (Green, Kahneman and Kunreuther 1994).

While including suggestions has no costs for fund-raisers, it is not at all clear whether they are beneficial to the cause or perhaps do harm. As presented in the next section, the literature is ambiguous. Our study delivers some promising evidence on the use of suggestions. While using large suggestions lowers the participate rates it increases the average donation given. The combined effect creates a higher return per mail-out in the presence of suggestions which in our data set is, however, not significant.

In the next section we discuss the relevant literature and explain how our study differs from past studies. In Section 3 we explain the experimental design and in Section 4 present the results. Section 5 reports on a one-year follow-up of the experiment and Section 6 compares our findings with the previous literature using some simple quantitative measure. Section 7 concludes.

\section{Literature}

There are a number of studies that test the effects of asking for small amounts (paltry donations). While all those studies find increased compliance, the effect on total contribution amounts differs. The field experiments by Brockner et. al (1984), Cialdini and Schroeder (1976), Reeves, Macolini, and Martin (1987), and Reingen (1978), who suggested in door-todoor solicitation campaigns that "Even a penny would help", show increases in total contributions. The lab experiments by Briers et al. (2007) with suggestions of $€ 0.5$ or $€ 3$ generates lower return as compared to no suggestion case. Weyant and Smith (1987) examine the effect of, both, small (penny) and large ("a generous contribution would really 
help") suggestions. They conduct two field experiments (door-to-door and mail-out) and conclude (p. 399): "in most practical circumstances requesting a large amount is counterproductive".

Fraser et al. (1988) test the effects of paltry and large donations in a door-to-door fundraising campaign. While a suggestion that "Even a penny would help" doubles the compliance rates, the average revenue is not significantly greater than the control. A suggestion of a large amount (\$20) more than doubled the revenue. In another door-to-door experiment analyzing suggestions two to three times larger than average (expected) donations Schwarzwald, Bizman and Raz (1983) find that the average donation given rises substantially with the suggested amount while the compliance rate remains unchanged in a group to which a relation has been established prior to the experiment (individuals who had previously agreed to sign a petition on the same subject as the donation campaign). In contrast, the group without an established relationship gave, on average, the same amount or less than without suggestions.

All of the above experiments deal with small-money fundraising, in the range of $\$ 1-\$ 10$. The conclusions from these studies might not hold for higher range donations. There are a number of experiments for middle-range donations analyzing the effects of donation grids, which differ from simple suggestion by offering arrays of amounts to choose from, e.g. $\$ 10, \$ 25$, $\$ 50, \$ 100$ or other. A field experiment by Doob and McLaughlin (1989) shows that past donors of a charitable organization facing a donation grid with higher amounts give, on average, significantly larger amounts without negative consequences for the response rate. Desmet and Feinberg (2003) analyze data from a large-scale experiment conducted in conjunction with a nationally operating French charity in order to test the effects of different donation grids. They find that different points on the grid exhibit significant downward and upward pulling effects. However, no particular superior grid emerges from the study. Prokopec and De Bruyn (2009) show that starting points on grids that exceed own past donations increase average donations, but on the other hand, reduce the response rate. De Bruyn and Prokopec (2010) show that individually tailored grids can increase the return from a donation campaign by as much as 36\%. Lee and Feinberg (2012) analyzed the effects of different grids on giving behavior by using data from a quasi-experiment conducted in conjunction with the same French charity. They find that donors are influenced by internal 
reference points and the grid. Specifically, they observe that grid design has a fourfold effect: upward compliance, downward compliance, upward pulling and downward pulling. Their combined effects are difficult to understand, and therefore it not possible to conclude whether the employment of multiple grids is useful at all. Using the best fit from their estimation they simulate the effects of a unique suggestion: either group tailored (using two groups and based on previous donation levels), or individually tailored (using individual donative history). While the simulations of a group-tailored suggestion increases returns by approx. $25 \%$, the individually tailored suggestions add only around $2 \%$ on top.

In a related study Marks, Schansberg and Croson (1999) conduct a laboratory experiment to examine the effects of nonbinding suggestions in a campaign employing the provision point mechanism. They do not find any differences in contribution levels between treatments with or without suggestions when subjects have identical endowments. However, if there is heterogeneity in endowments, the authors find that (heterogeneous) suggestions increase individual contributions in comparison to the case without suggestion. Croson and Marks (2001) find in a lab experiment that recommending contributions eases the coordination on the Nash equilibrium outcome in a threshold public good provision game when the contributors value the good differently. Again there is no effect when agents are homogenous.

In a field experiment, Shang and Croson (2009) test the effect of social information on the level of gifts. Although the experiment does not consider direct contribution-level suggestions, the authors find that, on average, new donors give more if they know that previous donors have chosen higher donations. They do not find such as effect for renewing donors, which might suggest that new donors are initially unsure about their own valuation of the project and their optimal contribution. Once they settle on a solution, the effect of new information becomes less important. Frey and Meier (2004) test the hypothesis of "conditional cooperation" in a field experiment and find that individuals at the margin of giving choose more often to donate when they know that many others contribute. Those who have strong or weak pro-social preferences are not influenced.

Almost all experiments testing paltry or higher-relative suggestions operate with small amounts (below $\$ 20$ ), often in a range of just $\$ 1$ or $\$ 2$. The exceptions are the studies of donation grids by Desmet and Feinberg (2003) and Lee and Feinberg (2012). Whereas the 
evidence for increasing return by using grids is mixed, Lee and Feinberg suggest that choosing an elevated request should generate better returns.

This study differs from others by studying the effect of larger relative suggestions in a field experiment based on a solicitation mail-out in the context of medium-level donations with employing single suggestions illustrated by describing what the suggested amounts would buy. Strictly speaking, this implies that we measure the combined effect of larger suggestions and information. However, as we vary the suggestion, holding the information constant, we will also learn about the pure suggestion effect.

\section{Experimental design}

In June 2011 the Bavarian State Opera sent out around 19,500 solicitation letters to opera visitors asking them to support a social youth project organized by the opera house. The project aimed to introduce school children from socially disadvantaged areas to classical music and opera. The recipients were randomly selected from the opera's database of customers who had purchased at least one ticket to attend either the opera or ballet in the twelve months prior to the mail-out. Recipients were randomly assigned to one of three treatment groups, and there were around 6,500 subjects per treatment. The $€ 100$ and $€ 200$ treatment differed from the no-suggestion treatment by one additional sentence: "Your donation of $€ 100$ (€200) makes the participation of 1 child ( 2 children) in our project possible". The precise format and wording of each mail-out letter is in the Appendix.

In Table 1, the random assignment of recipients into treatments is analyzed. A number of recipient characteristics are available in the opera house's database, which records details on individuals that have purchased an opera ticket in a recent past. Given randomization, recipients are not significantly different to each other across the treatments, as confirmed by all t-tests of equality of means for the available variables: female dummy, couple dummy, academic title dummy ( $\mathrm{PhD}$ or professor), noble title dummy ${ }^{1}$ and a dummy variable identifying Munich residents.

\footnotetext{
${ }^{1}$ The noble title dummy classifies individuals as such if they have a formal aristocratic title. It includes the following titles: Baron/Baronin (Freiherr/Freifrau), and Graf/Gräfin which is a historical German noble title similar in rank to a count or a British earl. The balance among treatment groups on this variable might be desirable in the context of
} 
Table 1: Random Assignment of Recipients into Treatments, 2011 Experiment Mean, standard error in parentheses

P-value on test of equality of means in box brackets

\begin{tabular}{cccccccc}
\hline $\begin{array}{c}\text { Treatment } \\
\text { description }\end{array}$ & $\begin{array}{l}\text { Comparisn } \\
\text { group }\end{array}$ & $\begin{array}{c}\text { Number of } \\
\text { recipients }\end{array}$ & $\begin{array}{c}\text { Female } \\
{[\text { Yes=1] }}\end{array}$ & $\begin{array}{c}\text { Couple } \\
\text { [Yes=1] }\end{array}$ & $\begin{array}{c}\text { PhD or } \\
\text { Professor } \\
{[\text { Yes=1] }}\end{array}$ & $\begin{array}{c}\text { Noble title } \\
{[\text { Yes=1] }}\end{array}$ & $\begin{array}{c}\text { Munich } \\
\text { resident } \\
{[\text { Yes=1] }}\end{array}$ \\
\hline $\begin{array}{c}\text { (1) No } \\
\text { suggestion }\end{array}$ & & 6457 & .552 & .029 & .140 & .003 & .257 \\
$(2) € 100$ & & & $(.006)$ & $(.002)$ & $(.004)$ & $(.001)$ & $(.005)$ \\
& & 6448 & .544 & .027 & .142 & .003 & .252 \\
$(3) € 200$ & & $(.006)$ & $(.002)$ & $(.004)$ & $(.001)$ & $(.005)$ \\
& & \multirow{2}{*}{6438} & .553 & .030 & .137 & .003 & .247 \\
& & & $(.006)$ & $(.002)$ & $(.004)$ & $(.001)$ & $(.005)$ \\
& & & {$[.366]$} & {$[.392]$} & {$[.800]$} & {$[.729]$} & {$[.568]$} \\
& $(1)=(2)$ & & {$[.882]$} & {$[.855]$} & {$[.564]$} & {$[.499]$} & {$[.211]$} \\
& $(1)=(3)$ & & {$[.292]$} & {$[.305]$} & {$[.407]$} & {$[.742]$} & {$[.495]$} \\
\hline
\end{tabular}

Notes: The tests of equality in box brackets are based on a mean comparison t-test against a two sided alternative hypothesis.

IV. Results

Table 2 presents descriptive statistics on donation outcomes for the three treatments. The mean amount given increases monotonically as we move from the top to the bottom of the table (€71.4, €88.17, and $€ 102.4$ respectively). The increase in average donation is not an effect of outliers. On the contrary, the highest donation without suggestion is $€ 800$, it is $€ 500$ with $€ 100$ suggested, and it is $€ 300$ with $€ 200$ suggested. Moving from the no-suggestion treatment to the $€ 200$ treatment, we observe an increase in the mean donation by $43 \%$ or $€ 31$. The difference between the no-suggestion and the $€ 100$ treatment is $24 \%$ or $€ 17$. The results are significant both for the $€ 100(\mathrm{p}=0.02)$ and the $€ 200(\mathrm{p}<0.001)$ suggestions. The median donations are $€ 50, € 100$, and $€ 100$.

In contrast, the participation rates decrease as we move from the top to the bottom of Table 2 $(3.10 \%, 2.80 \%$, and $2.30 \%$ respectively). The reduction amounts to $26 \%$ if we move from the

charitable giving and German context as we might expect those individuals to have long philanthropic associations with arts and culture. 
no-suggestion treatment to the $€ 200$ treatment. The effect of suggesting the $€ 200$ is statistically significant $(\mathrm{p}=0.08)$. The effect of suggesting $€ 100$ on participation rate is not statistically significant.

The return per mail, which is a combination of the two previous effects, is between $€ 2.24$ and $€ 2.52$ in the treatments. Suggesting $€ 100$ increases the return by 28 cents per mail-out but the effect is not statistically significant. The increase in the $€ 200$ treatment is slightly smaller and also not statistically significant.

Table 2: Outcomes, 2011 Experiment

Mean, standard error in parentheses

P-value on test of equality of means in box brackets

\begin{tabular}{|c|c|c|c|c|c|}
\hline $\begin{array}{l}\text { Treatment } \\
\text { description }\end{array}$ & $\begin{array}{c}\text { Comparison } \\
\text { group }\end{array}$ & $\begin{array}{c}\text { Number of } \\
\text { recipients }\end{array}$ & $\begin{array}{l}\text { Response } \\
\text { Rate }\end{array}$ & $\begin{array}{c}\text { Mean } \\
\text { Donation }\end{array}$ & $\begin{array}{l}\text { Average } \\
\text { Return }\end{array}$ \\
\hline \multirow[t]{2}{*}{ (1) No suggestion } & & 6457 & .031 & 71.4 & 2.24 \\
\hline & & & $(.002)$ & (5.61) & $(.234)$ \\
\hline \multirow[t]{2}{*}{ (1) $€ 100$} & & 6448 & .028 & 88.17 & 2.52 \\
\hline & & & $(.002)$ & (4.07) & $(.216)$ \\
\hline \multirow[t]{5}{*}{ (2) $€ 200$} & & 6438 & .023 & 102.4 & .2 .40 \\
\hline & & & $(.002)$ & $(5.77)$ & $(.236)$ \\
\hline & $(1)=(2)$ & & {$[.385]$} & {$[.018]$} & {$[.394]$} \\
\hline & $(1)=(3)$ & & {$[.008]$} & {$[.000]$} & {$[.634]$} \\
\hline & $(2)=(3)$ & & {$[.008]$} & [.039] & {$[.723]$} \\
\hline
\end{tabular}

Notes: All monetary amounts are measured in Euros. The tests of equality in box brackets are based on a mean comparison t-test against a two sided alternative hypothesis. Mean donations are conditional on giving.

Figure 1 shows the distribution of donation amounts by treatment, and Table 3 summarizes and compares the frequencies of giving particular amounts (€50, €100, and €200) conditional on giving. In the no-suggestion treatment, the $€ 50$ donation is chosen most frequently (in $36 \%$ of cases), followed by the donation of $€ 100$ (17.9\%). In the $€ 100$ treatment the donation of $€ 100$ is clearly most often chosen, i.e., in $54.3 \%$ of cases. In the $€ 200$ treatment, the amounts $€ 50, € 100$ and $€ 200$ are chosen similarly often $(24.5 \%, 24.5 \%$, and $21.9 \%$ respectively). 
Compared to the no-suggestion and $€ 100$ treatment the frequency of $€ 200$ donations is striking. It is seven times larger than in the no-suggestion and four times larger than in the $€ 100$ treatment. These treatment effects are all confirmed as statistically significant: giving $€ 50$ is more frequent in the no-suggestion treatment than in the others, similarly, giving $€ 100$ in the $€ 100$ treatment and giving $€ 200$ in $€ 200$ treatment. Figure 2 illustrates our treatment effects by plotting differences in distributions from which treatments differences emerge even more clearly.

Figure 1: Distribution of donations by treatment, 2011 Experiment

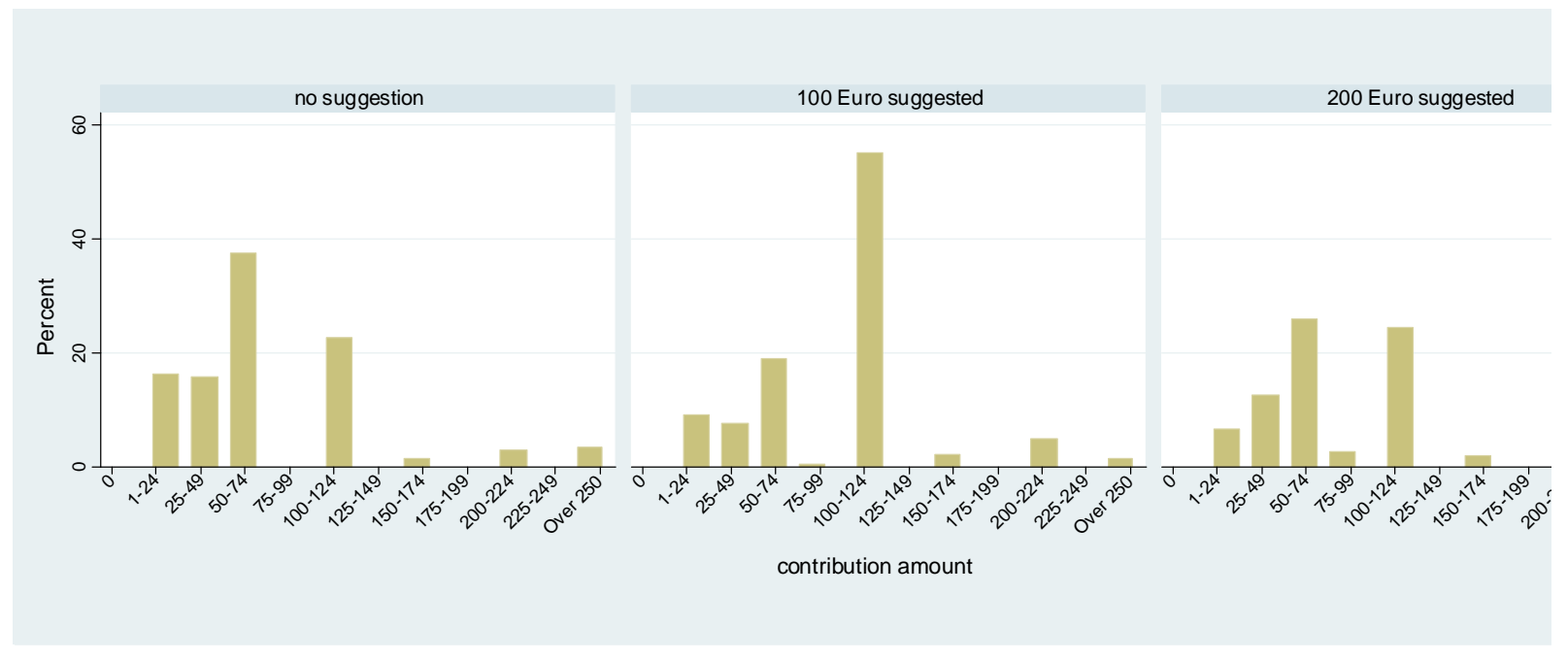


Figure 2: Differences in frequencies, 2011 Experiment

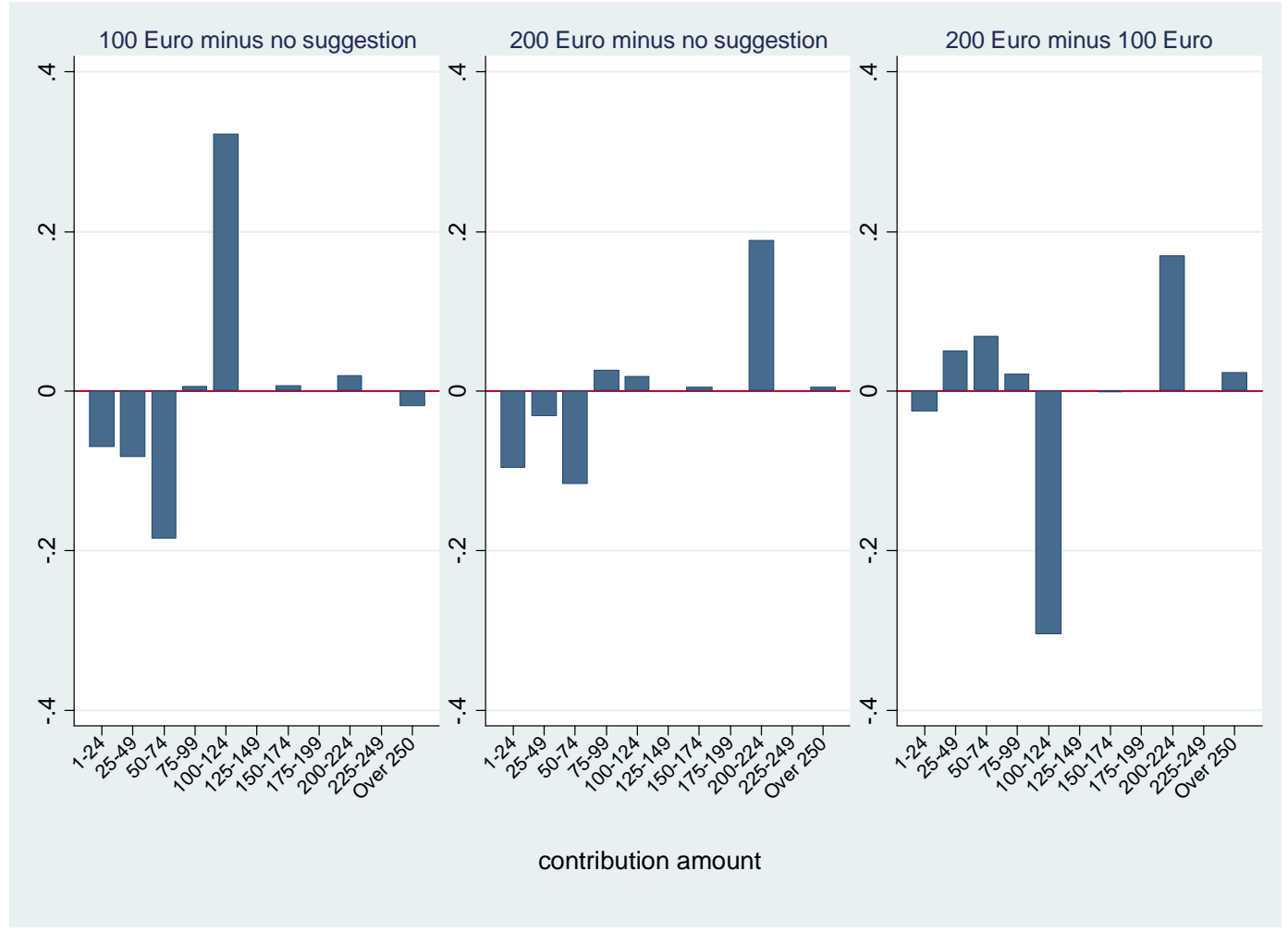

Table 3: Test of differences in distribution among treatments, 2011 Experiment

Mean, standard error in parentheses

P-value on test of equality of means in box brackets

\begin{tabular}{|c|c|c|c|c|c|}
\hline $\begin{array}{l}\text { Treatment } \\
\text { description }\end{array}$ & $\begin{array}{c}\text { Comparison } \\
\text { group }\end{array}$ & $\begin{array}{c}\text { Number of } \\
\text { donations }\end{array}$ & $\begin{array}{l}\text { Frequency of } \\
\text { giving } € 50\end{array}$ & $\begin{array}{c}\text { Frequency of } \\
\text { giving } € 100\end{array}$ & $\begin{array}{l}\text { Frequency of } \\
\text { giving } € 200\end{array}$ \\
\hline \multirow{2}{*}{$\begin{array}{c}\text { (1) No } \\
\text { suggestion }\end{array}$} & & 203 & .360 & .227 & .030 \\
\hline & & & $(.034)$ & $(.029)$ & $(.012)$ \\
\hline \multirow[t]{2}{*}{ (2) $€ 100$} & & 184 & .179 & .543 & .049 \\
\hline & & & $(.028)$ & $(.037)$ & $(.016)$ \\
\hline \multirow[t]{5}{*}{ (3) €200 } & & 151 & .245 & .245 & .219 \\
\hline & & & $(.035)$ & $(.035)$ & $(.034)$ \\
\hline & $(1)=(2)$ & & {$[.000]$} & {$[.000]$} & [.326] \\
\hline & $(1)=(3)$ & & [.021] & [.687] & {$[.000]$} \\
\hline & $(2)=(3)$ & & {$[.142]$} & {$[.000]$} & {$[.000]$} \\
\hline
\end{tabular}

Notes: The tests of equality in box brackets are based on a mean comparison t-test against a two sided alternative hypothesis. Propensity of giving $€ X X$ is conditional on giving. 
Lee and Feinberg (2012) analyze the attraction effects of suggested amounts on a grid. However, because we lack information about individual internal reference points, in what follows we present a simplified version of such attraction effects. We calculate distances between own donation and $€ 100$ ( $€ 200$ respectively) and test whether average distances differ among treatments. Table 4 summarizes the results, which are divided in lower, upper and combined distance. Tests confirm that the average distance to $€ 100$ (€200) is smaller when the $€ 100$ (€200) suggestion is made.

Given the available information on donors' characteristics it is worthwhile to see how those characteristics correlate with the probability of giving, separately from treatment effects. Table 5 presents probit results for the full sample. In model (1) only treatment assignment dummies are included (with the no-suggestion treatment being the omitted group), while model (2) conditions on all available characteristics. The second and fourth column show coefficient estimates, and the third and fifth columns show marginal effects.

In the first specification conditioning only on treatment assignment, we see that relative to the no-suggestion treatment, individuals in the $€ 200$ treatment are less likely to donate. In the second specification once individual covariates are included, we find that couples, individuals with academic title and Munich residents are significantly more likely to give. Women are less likely to give (an effect significant at the $10 \%$ level). In an estimation with interaction effects, the interaction effects are not statistically significant, with the only exception of individuals with an academic title giving more in $€ 200$ treatment, significant at $10 \%$ level. Regarding donation amounts, we find no evidence of any significant interaction effects. ${ }^{2}$

\footnotetext{
${ }^{2}$ For one third of individuals we also have information on the average value of tickets bought in 2009 . Using this ticket price data as a proxy for wealth, we find that the effects of suggestions are robust. While wealthier individuals are more likely to give and also give larger amounts, there are no interactions between wealth and suggested contribution levels.
} 
Table 4: Average distance, 2011 Experiment

Mean, standard error in parentheses, $\mathrm{N}$ number of observations

P-value on test of equality of means in box brackets

\begin{tabular}{|c|c|c|c|c|c|c|c|}
\hline $\begin{array}{l}\text { Treatment } \\
\text { description }\end{array}$ & $\begin{array}{l}\text { Comparison } \\
\text { group }\end{array}$ & $\begin{array}{c}\text { Average } \\
\text { distance to } \\
€ 100, \\
d<=100\end{array}$ & $\begin{array}{c}\text { Average } \\
\text { distance to } \\
€ 100, \\
d>=100\end{array}$ & $\begin{array}{l}\text { Average } \\
\text { distance to } \\
€ 100, \\
\text { combined }\end{array}$ & $\begin{array}{c}\text { Average } \\
\text { distance to } \\
€ 200, \\
\mathrm{~d}<=200\end{array}$ & $\begin{array}{c}\text { Average } \\
\text { distance to } \\
€ 200, \\
\mathrm{~d}>=200\end{array}$ & $\begin{array}{c}\text { Average } \\
\text { distance to } \\
€ 200, \\
\text { combined }\end{array}$ \\
\hline \multirow{3}{*}{$\begin{array}{c}\text { (1) No } \\
\text { suggestion }\end{array}$} & & 46.04 & 45.16 & 56.21 & 140.1 & 103.85 & 141.92 \\
\hline & & (2.14) & (14.3) & $(4.46)$ & (2.84) & $(47.52)$ & (3.69) \\
\hline & & $\mathrm{N}=187$ & $\mathrm{~N}=62$ & $\mathrm{~N}=203$ & $\mathrm{~N}=196$ & $\mathrm{~N}=13$ & $\mathrm{~N}=203$ \\
\hline \multirow[t]{3}{*}{ (2) $€ 100$} & & 24.23 & 15.98 & 32.16 & 116.17 & 37.5 & 116.72 \\
\hline & & $(2.42)$ & $(4.65)$ & $(3.41)$ & (3.10) & $(25.47)$ & $(3.23)$ \\
\hline & & $N=167$ & $\mathrm{~N}=117$ & $\mathrm{~N}=184$ & $\mathrm{~N}=181$ & $\mathrm{~N}=12$ & $\mathrm{~N}=184$ \\
\hline \multirow[t]{6}{*}{ (3) €200 } & & 37.46 & 56.33 & 56.51 & 104.37 & 10.26 & 102.87 \\
\hline & & (2.85) & (6.46) & (3.48) & (5.28) & $(4.18)$ & (5.12) \\
\hline & & $\mathrm{N}=109$ & $\mathrm{~N}=79$ & $\mathrm{~N}=151$ & $\mathrm{~N}=145$ & $\mathrm{~N}=39$ & $\mathrm{~N}=151$ \\
\hline & $(1)=(2)$ & {$[0.00]$} & [0.02] & {$[0.00]$} & {$[0.00]$} & [0.24] & {$[0.00]$} \\
\hline & $(1)=(3)$ & [0.02] & {$[0.45]$} & [0.96] & {$[0.00]$} & {$[0.00]$} & {$[0.00]$} \\
\hline & $(2)=(3)$ & {$[0.00]$} & {$[0.00]$} & {$[0.00]$} & {$[0.04]$} & [0.09] & {$[0.02]$} \\
\hline
\end{tabular}

Notes: The tests of equality in box brackets are based on a mean comparison t-test against a two sided alternative hypothesis. 
Table 5: Probability of Donation: Probit Regression, 2011 Experiment

(Dependent variable DONATE $\in\{0,1\}$ )

(1)

Coeff.

(Std. Err.)

$€ 100$

$-0.0427$

(0.0442)

$€ 200$

$-0.127 * *$

(0.0458)

Female

Couple

PhD or Professor

Noble title

Munich resident
(2)

$\begin{gathered}\text { Marginal effect* } \\ \text { (percentage } \\ \text { points) }\end{gathered}$
-0.30
-0.90

Coeff.

(Std. Err.)

$-0.0429$

$(0.0445)$

$-0.126 * *$

(0.0461)

$-0.0676+$

(0.0391)

$-0.43$

$0.305^{* * *}$

(0.0908)

1.93

$0.142 * *$

0.90

(0.0501)

0.149

(0.319)

0.94

$0.198 * * *$

(0.0403)

1.25

$-1.917 * * *$

(0.0410)

19343

Observations (0.0307)

19343

$-2428.4876$

Note: $* d y / d x$ is for discrete change of dummy variable from 0 to 1 . Basis at all dummy variables set to 0 , i.e., for the second specification male, no academic or noble title, nor a Munich resident.

Standard errors in parentheses

$+p<0.1,{ }^{*} p<0.05,{ }^{* *} p<0.01,{ }^{* * *} p<0.001$

\section{Follow-up experiment}

In July 2012 the opera house launched a second fundraising campaign for the same project with 20,000 letters sent to regular operagoers. This mail-out reached around $50 \%$ of the previous sample. Others dropped out as they had not purchased a ticket in the last 12 months or had changed their address or name. There were no experimental variations in this 2012 fundraising campaign. 
Table 6 summarizes the frequencies for the exact donations of $€ 50, € 100$, or $€ 200$. While among those who were previously in the no-suggestion treatment, the donation of $€ 50$ is most common (36.6\%) followed by $€ 100$ (26.8\%), this pattern is reversed among those who were randomly assigned to the $€ 100$ treatment a year before (€100 with $28.9 \%$ and $€ 50$ with $25 \%$ ). Finally, we find that those who were previously in the $€ 200$ treatment are still far more likely to give $€ 200$ : $6 \%$ versus $4.7 \%$ and $1.6 \%$ for those who were earlier in the $€ 100$ and nosuggestion treatments respectively with the difference to the latter being statistically significant. In other words, there appears to be a clear echo of the 2011 treatments in 2012.

Table 6: Test of differences in distribution among treatments, a year later (2012)

Mean, standard error in parentheses

P-value on test of equality of means in box brackets

\begin{tabular}{|c|c|c|c|c|c|}
\hline $\begin{array}{c}\text { Treatment } \\
\text { description }\end{array}$ & $\begin{array}{c}\text { Comparison } \\
\text { group }\end{array}$ & $\begin{array}{c}\text { Number of } \\
\text { recipients }\end{array}$ & $\begin{array}{l}\text { Frequency of } \\
\text { giving } € 50\end{array}$ & $\begin{array}{c}\text { Frequency of } \\
\text { giving } € 100\end{array}$ & $\begin{array}{c}\text { Frequency of } \\
\text { giving } € 200\end{array}$ \\
\hline \multirow{2}{*}{$\begin{array}{c}\text { (1)No } \\
\text { suggestion }\end{array}$} & & 123 & .366 & .268 & .016 \\
\hline & & & $(.044)$ & $(.040)$ & $(.011)$ \\
\hline \multirow[t]{2}{*}{$(2) € 100$} & & 128 & .250 & .289 & .047 \\
\hline & & & $(.038)$ & $(.040)$ & $(.019)$ \\
\hline \multirow[t]{5}{*}{ (3) $€ 200$} & & 133 & .383 & .241 & .060 \\
\hline & & & $(.042)$ & $(.037)$ & $(.021)$ \\
\hline & $(1)=(2)$ & & [.047] & [.715] & [.169] \\
\hline & $(1)=(3)$ & & [.772] & [.613] & {$[.071]$} \\
\hline & $(2)=(3)$ & & [.021] & [.377] & [.636] \\
\hline
\end{tabular}

Notes: The tests of equality in box brackets are based on a mean comparison t-test against a two sided alternative hypothesis. Frequency of giving $€ X X$ is conditional on giving.

VI Comparing the effects of suggestions across the literature

While we have emphasized that our experiment differs from the previous literature in suggesting much larger amounts to the recipients of a fundraising call it is interesting to compare our observations to previous data. Both, Figures 4 and 5, plot data from all 
experiments that we have discussed including our own. On the x-axis we have the relative size of the suggestion or, more precisely, the suggested level divided by the average donation in the absence of a suggestion. While Figure 4 shows the relative change in the average donation (conditional on giving), Figure 5 shows the relative change in the response rate. Two clear patterns emerge from these figures. Donations can be systematically pushed up through higher relative suggestions but response rates decline. The empirical tradeoff between these measures is shown in Figure 6. While there are is only one study that has documented an increase in response rate and donation size, there are quite a few northeast of the iso-income curve going through $(1,1)$.

Figure 4: Relative change in the average donation (conditional on giving)

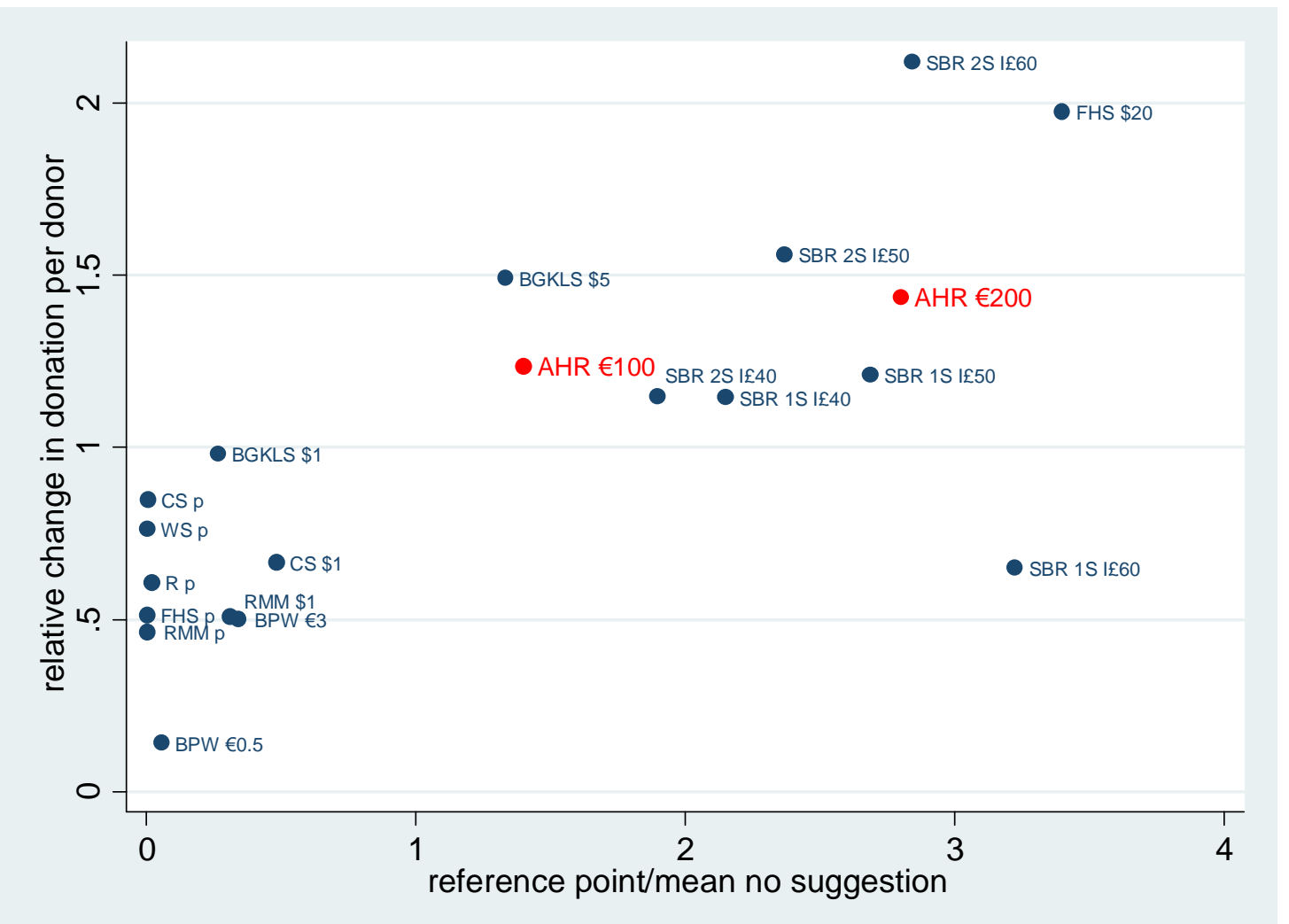

Notes: In studies and treatments using suggestions "even a penny will help", we use the face value 0.01 of respective currency as a suggestion. We omit studies and treatments for which this quantification is not possible, e.g. Weyant, Smith (1987) "a generous contribution would really help.” BPW €0.5 - Briers et al. (2007), study 3, €0.5; BPW €3 - Briers et al. (2007), study 3, $€ 3$; FHS \$20 - Fraser et al. (1988) \$20; FHS p - Fraser et al. (1988) penny; BGKLS \$1 - Brockner et al. (1984) \$1; BGKLS \$5 Brockner et al. (1984) \$5; CS \$1 - Cialdini, Schröder (1976) \$1; CS p - Cialdini, Schröder (1976) penny; RMM \$1 - Reeeves et al. (1987) \$1; RMM p - Reeeves et al. (1987) penny; R p - Reingen (1978) penny; SBR 2S I£40 - Schwarzwald et al. (1983) two stage I£40; SBR 2S I£50 - Schwarzwald et al. (1983) two stage I£50; SBR 2S I£60 - Schwarzwald et al. (1983) two stage I£60; SBR 1S I£40 - Schwarzwald et al. (1983) one stage I£40; SBR 1S I£50 - Schwarzwald et al. (1983) one stage I£50; SBR 1S I£60 - Schwarzwald et al. (1983) one stage I£60; WS p - Weyant, Smith (1987) penny; AHR €100 - this study €100; AHR €200 this study $€ 200$. 
Figure 5: Relative change in the response rate

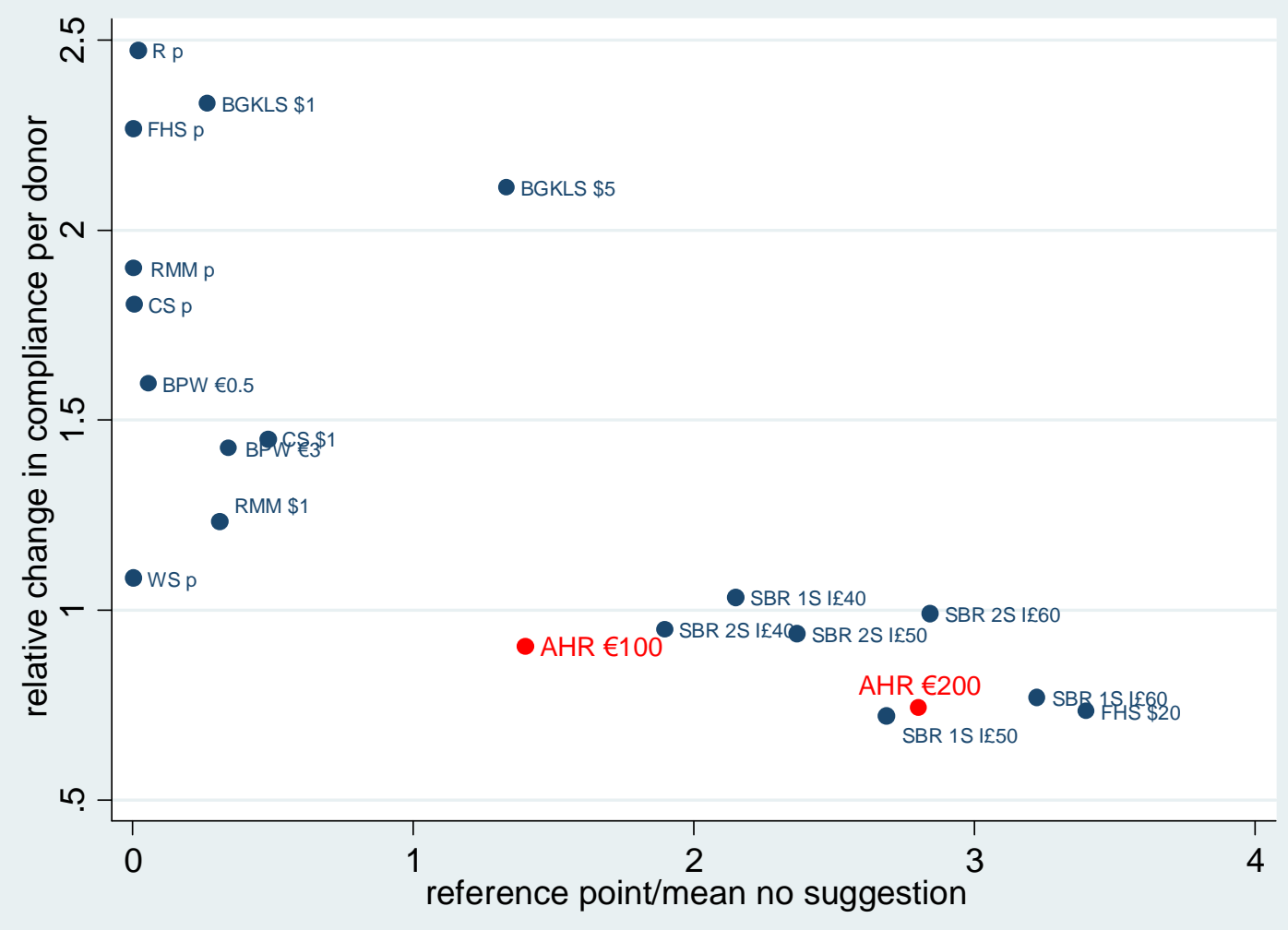

Notes: See notes for Figure 4.

\section{Discussion}

We find that nonbinding suggestions have effects on contribution-level choices in fundraising calls for a charitable project. The suggestions substantially change the distribution of donations, with large shares of donors complying with the suggestions. While higher suggestions lower response rates, they increase the average donation given. The combined effect is a weak (non-significant) increase in the average return per letter. Given that the suggestions were not tailored our results strongly suggest that suggestions, if chosen in a sophisticated manner, have the power substantially to increase fundraising returns. We plan to explore tailored fundraising in a future study. 
Figure 6: Trade-off between the relative change in the average donation (conditional on giving) and in the response rate

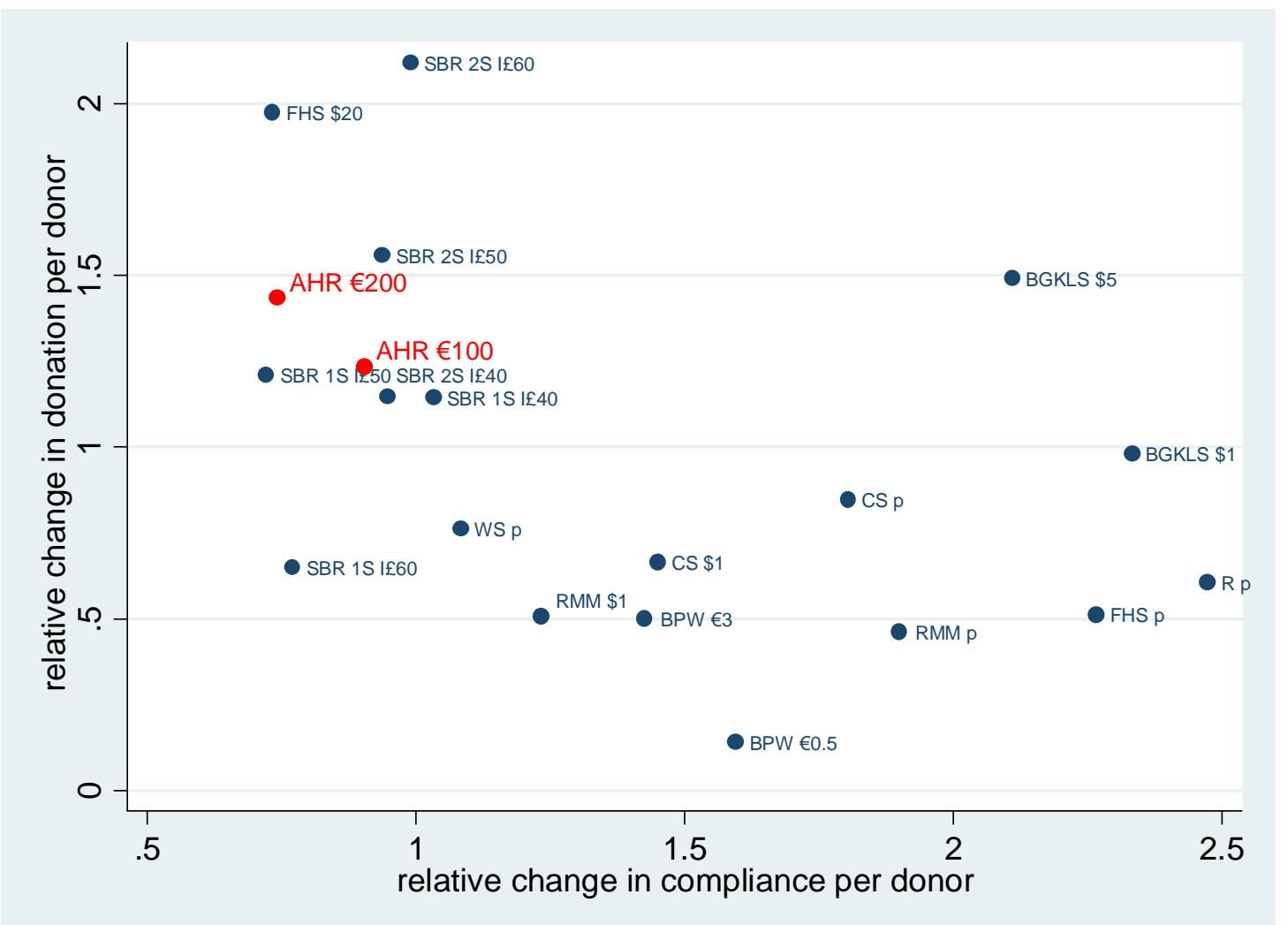

Notes: See notes for Figure 4.

We should note that, strictly speaking, we examine the combined effect of large suggestions (that is, suggestions above the mean and median) and some information about the costs function for the project. Of course, when we compare the two treatments with suggestions we keep that information constant and observe a strong pure suggestion effect. We believe that for large suggestions it is natural for charities to offer some kind of information that justifies the large amounts suggested and as such we have explored a natural starting point.

From a broader perspective, our results suggest that when receiving a solicitation letter many individuals are unsure about the optimal donation level. A suggestion offers guidance (in particular when combined with some information about what kind of difference one makes by 
choosing the suggested amount). This has some similarity with the effects of social information as documented by Frey and Meier (2004) or Shang and Croson (2009).

From an economic theory point of view, our results hint at possibly important drivers of behavior. The drop in the response rate suggests that there is a discouragement effect operating which could be driven by either embarrassment (about giving paltry amounts) or an implicit desire to compete with others (for some kind of social recognition from the charity) that is frustrated when one learns that apparently large amounts have to be offered if one wants to be viewed as a significant contributor. At the same time we observe that the distribution of donations becomes more compressed at the top when suggested amounts increase. Speculatively, this might suggest that some (wealthy) donors want to make sure they give what is expected and that suggestions could lower their contributions. This area is worth exploring in future research.

Our results are also suggestive of interesting, dynamic hysteresis in giving behavior. As the treatment-specific giving patterns persist a year later without new suggestions being made, this might support the hypothesis that donors learn their optimal contribution. While the adverse effect of high suggestions on response rates disappears a year later (at least some of) the donors appear to have internalized a new higher reference point. This is another interesting avenue for further research.

\section{Bibliography}

Barbara Briers, Mario Pandelaere, and Luk Warlop (2007), Adding exchange to charity: A reference price explanation. Journal of Economic Psychology, Volume 28, Issue 1, January 2007, 15-30. http://dx.doi.org/10.1016/j.joep.2005.12.001

Brockner, Joel, Beth Guzzi, Julie Kane, Ellen Levine, and Kate Shaplen (1984), "Organizational Fundraising: Further Evidence on the Effect of Legitimizing Small Donations," Journal of Consumer Research, 11 (June), 611-614. 
Cialdini, Robert B. and David A. Schroeder (1976), "Increasing Compliance by Legitimizing Paltry Contributions: When Even a Penny Helps," Journal of Personality and Social Psychology, 34 (October), 599-604.

De Bruyn, Arnaud, Sonja Prokopec (2010), "Optimizing Donations with IndividuallyTailored Donation Grids: An Econometric Model of Compliance and Generosity," in Proceedings of the 37th EMAC Conference, Suzanne C. Beckmann and Torsten Ringberg (Ed.), Copenhagen: European Marketing Academy.

Desmet, P. and F.M. Feinberg (2003), “Ask and ye shall receive: The effect of the appeals scale on consumers' donation behavior." Journal of Economic Psychology 24 (3):349-376.

Doob, A.N. and D.S. McLaughlin (1989), “Ask and You Shall be Given: Request Size and Donations to a Good Cause." Journal of Applied Social Psychology 19 (12):1049-1056.

Fraser, C., R.E. Hite, and P.L. Sauer (1988), "Increasing Contributions in Solicitation Campaigns: The Use of Large and Small Anchor Points." Journal of Consumer Research 15 (3):284-287.

Frey, Bruno S., and Stephan Meier (2004), "Social Comparisons and Pro-Social Behavior: Testing "Conditional Cooperation" in a Field Experiment," The American Economic Review , 94 (5):1717-1722

Marks, M. B., Schansberg, D. E. and Croson, R. T.A. (1999), "Using Suggested Contributions in Fundraising for Public Good. Nonprofit Management and Leadership," 9: 369-384. doi: 10.1002/nml.9403

Prokopec, Sonja, Arnaud De Bruyn (2009), "The Impact of Anchors on Donors' Behavior: A Field Experiment," in Proceedings of the ACR Annual North American Conference, Margaret C. Campbell, Jeff Inman, and Rik Pieters (Ed.), Pittsburgh: Association for Consumer Research.

Reeves, Robert A., Ruthann M. Macolini, and Roy C. Mar- tin (1987), "Legitimizing Paltry Contributions: On- the-Spot vs. Mail-in Requests," Journal of Applied Social Psychology, 17 (8), 731-738. 
Reingen, Peter (1978), "On Inducing Compliance with Re- quests," Journal of Consumer Research, 5 (September), 96-102.

Schwarzwald, Joseph, Aharon Bizman, and Moshe Raz (1983), "The Foot-in-the-Door Paradigm: Effects of Second Request Size on Donation Probability and Donor Generosity," Personality and Social Psychology Bulletin, 9 (September) 443-450.

Shang, J. and Croson, R. (2009), “A Field Experiment in Charitable Contribution: The Impact of Social Information on the Voluntary Provision of Public Goods." The Economic Journal, 119: 1422-1439. doi: 10.1111/j.1468-0297.2009.02267.x

Weyant, J.M. and S.L. Smith (1987), "Getting More by Asking for Less: The Effect of Request Size on Donations of Charity." Journal of Applied Social Psychology 17 (4): 392400. 


\section{Appendix}

\section{A) Mail-out letter}

Bringen Sie Kinder in die Oper!

die Kluft zwischen Arm und Reich wächst - auch in Deutschland. Besonders für Kinder und Jugendliche hat dies folgenschwere Auswirkungen. Während Familien mit hohem Einkommen die Möglichkeit haben, ihren Kindern eine erstklassige Ausbildung zu bieten, sind die Möglichkeiten für Kinder aus einem sozial benachteiligten Umfeld äußerst begrenzt.

Die Bayerische Staatsoper engagiert sich seit Jahren dafür, die kulturelle Bildung von Schülern aus sozial schwächeren Milieus zu stärken, um dieser Entwicklung entgegenzuwirken. Das Projekt „,OperÜberLeben“ wurde ins Leben gerufen, um in enger Zusammenarbeit mit Schulen und Lehrern die Kunstform Oper für Kinder erlebbar zu machen.

Da uns für derartige Projekte kaum eigene Mittel zur Verfügung stehen, ist die Bayerische Staatsoper hierbei überwiegend auf Spenden angewiesen.

A) Helfen auch Sie! Mit Ihrem Engagement tragen Sie dazu bei, dass der Zugang zur Erlebniswelt Oper für junge Generationen ermöglicht wird.

B) Helfen auch Sie! Mit Ihrem Engagement tragen Sie dazu bei, dass der Zugang zur Erlebniswelt Oper für junge Generationen ermöglicht wird. Mit einer Spende von EUR 100,- ermöglichen Sie einem Kind die Teilnahme am Projekt.

C) Helfen auch Sie! Mit Ihrem Engagement tragen Sie dazu bei, dass der Zugang zur Erlebniswelt Oper für junge Generationen ermöglicht wird. Mit einer Spende von EUR 200,- ermöglichen Sie bereits zwei Kindern die Teilnahme am Projekt.

Als Dankeschön können Sie einen Opernbesuch in meiner Loge für 2 Personen oder eine von 10 signierten CDs gewinnen.

Weitere Informationen finden Sie in der beiliegenden Projektbeschreibung. Bei Fragen steht Ihnen das Development-Team (Tel. XXXXXXX) gerne zur Verfügung.

Herzlichen Dank für Ihre Unterstützung.

Mit freundlichen Grüßen

XXX, Staatsintendant 


\section{B) Mail-out letter -Translation}

\section{Bring children to the opera!}

the gap between rich and poor is increasing - in Germany, too. Especially children and adolescents are exposed to momentous consequences. Families with high income have the possibility to provide their children with a first-class education. On the other hand chances for children from a socially disadvantaged environment are extremely limited.

The Bavarian State Opera House has been investing in the cultural education of children and youths from socially deprived milieus for several years now to counteract this development. The programme "OperÜberLeben" [OperaOverLife] has been launched in close collaboration with schools and teachers to enable a playful introduction of the art form opera for children.

Since we have extremely limited own funds for this project, the Bavarian State Opera House is reliant on the help of private donations.

A) Please help as well! With your commitment you will contribute to the chance for access of the young generation to the opera as a world of new experience.

B) Please help as well! With your commitment you will contribute to the chance for access of the young generation to the opera as a world of new experience. With a donation of $€ 100$ you will give a child the possibility to participate in the programme.

C) Please help as well! With your commitment you will contribute to the chance for access of the young generation to the opera as a world of new experience. With a donation of $€ 200$ you will already give two children the possibility to participate in the programme.

As a thank you we will give away a pair of opera tickets for my box seat as well as ten signed CD's.

You can find all further information in the enclosed material. In case of any questions please give our Development team a ring on $[\mathrm{XXXX}]$.

With many thanks for your support and best wishes,

Sir XXX, Staatsintendant. 